\title{
The Role of Fintech and Financial Literacy on SMEs Sustainability
}

\author{
Winarsih $^{1}$, Mutoharoh $^{2}$, Emisa Tahar ${ }^{3}$, Inayah Abdul Aziz \\ Dept. of Accounting, Faculty of Economics, Universitas Islam Sultan Agung, \\ Semarang, Indonesia ${ }^{1,2,3,4}$ \\ \{winarsih@unissula.ac.id ${ }^{1}$, mutoharoh@unissula.ac.id $\left.{ }^{2}\right\}$
}

\begin{abstract}
Small and Medium Enterprises (SMEs) is a worldwide economy whose development is still constrained in various fields. One of the obstacles is in the financial sector. In this digitalization era, financial technology (fintech) can be widely used because of the increasing penetration of internet users. Nevertheless, SMEs actors are expected to be selective in choosing fin-tech. This aims to avoid losses, so that the SMEs sustainability is created. This study determined the effect of financial technology (fintech) used by SMEs actors on business sustainability mediated by financial literacy. This study used purposive sampling method and involved 300 respondents who are SME actors in Semarang, Kudus and Surakarta. The results of this study indicated that financial technology (fintech) is proven to have a positive effect on financial literacy. Likewise, financial literacy is proven to mediate the relationship of fintech on business sustainability. Thus, SME actors must understand knowledge in the field of financial literacy in order to make the best decisions and the business can develop properly. As the result, the business continuity can be maintained.
\end{abstract}

Keywords: Fintech, Financial Literacy, SMEs, Sustainability

\section{Introduction}

The existence of small and medium industries (IKM) plays a strategic role in improving Indonesia economy, especially in facing ASEAN economic community. Specifically, the existence of SMEs is believed to be able to contribute to alleviate poverty through job creation (Carrer and Klomp, 1996; Adomoko, Danso, and Damoah, 2016). The contribution of SMEs for national gross domestic product (GDP) is $57.6 \%$, and absorbs a workforce of $96.7 \%$ from the total workers in Indonesia

As one of the driving in Indonesia economy, the growth of SMEs needs to be increased through various facilities, including access to capital and marketing. Problems that often arise from the capital aspect are inadequate access to banking facilities and financial literacy. As the result, the network distribution of formal financial services institutions is uneven, due to the geographic structure and dispersed population and low financial literacy. If SME actors have an understanding on financial literacy, the management and accountability can be properly accounted for, so that it will have an impact on business sustainability. 
Business sustainability is a form of consistency in business conditions. It is also a process for the ongoing business, including growth, development and strategies to maintain business sustainability and resilience. Therefore, the government, through financial service authority (OJK) collaborates with the Ministry of Finance and Bank Indonesia, develop fintech in Indonesia.

Fintech is a technology-based financial service with various services that are considered safer, faster, and more practical. It is because the use of e-cash (electronic money) as a means of payment. In addition, there are advantages such as transparent management and transactions that can cross regional boundaries. Thus this digital payment provides an advantage for micro, small and medium enterprises.

Based on the background of the study, the problem formulation is; does financial literacy mediate the relationship between fintech and business sustainability?

The purpose of this study is to determine the role of financial literacy in mediating the relationship between fintech and business sustainability. Thus the contribution in this research is as a discourse for knowledge development in the field of financial planning, financial services. Furthermore, this study also contributes as an input in formulating policies related to the role of fintech in increasing financial literacy of SMEs, so that the business sustainability can be improved.

\section{Literature Review}

\subsection{Financial Technology (Fintech)}

Fintech is an innovation in financial sector that gets a touch of modern technology. Fintech industry (financial technology) is one of the methods of financial services in digital era, where digital payment is one of the most developed sectors. This sector is then the most expected by the Indonesia government and society to gain an increase in the number of people who have access to financial services.

The development of fintech has become a tangible manifestation of technological development [3] and has disrupted the banking sector [20], [18]. Stated that the presence of fintech was able to increase $75 \%$ of the population towards financial literacy and inclusion [8]. Through innovation and technology-based financial products, it will have the ability to encourage financial inclusion in the future [12].

Fintech with financial services such as crowdfunding, mobile payments and money transfer services result a revolution in the startup business. Fintech also has an important role in changing consumer behavior and expectations, including: a.) can access data and information anytime and anywhere. b) generalizing large and small businesses so that they tend to have high expectations even for small and newly built business.

Globally, fintech industry continues to grow rapidly. This is proven by the emergence of startup companies and the huge amount of global investment in it. Especially in Indonesia, this business is growing rapidly and attracting the attention of all business actors in Indonesia. The fintech services for SMEs are such as corporate capital loans, digital payment services and financial regulatory service. 


\subsection{Financial Literacy}

Financial literacy is the ability and knowledge of finances of a person has to manage his certain amount of money in order to improve his life standard [17]. Therefore, financial literacy is related to behavior, habits and external factors. In addition, it is defined as the level of knowledge, skills and confidence, which influence attitudes and behavior.

Financial literacy aims to improve the quality of decision making and financial management, so that the welfare of the wider community can be achieved. In financial literacy, there is an index as a value measured based on several components, such as financial knowledge. Financial knowledge is the individual decision making that uses a combination of skills, resources and contextual knowledge to manage information and make decisions. A good understanding of financial literacy, entrepreneurs are able to use their skills in the financial field for making the right decisions.

The level of financial literacy from an individual or family point of view has an impact on the ability to have long-term savings that are used to own a number of assets, such as land or houses, education and future savings. If the money management is not effective, it will have an impact on the family financial crisis [4]. SMEs that have good financial literacy will be able to achieve their company goals, and have a business development orientation. Furthermore, financial literacy helps a person to survive in difficult economic conditions and increase the company growth [7].

\subsection{Business Sustainability}

Business sustainability is a state or condition where there are ways to maintain, protect and develop the resources of business. Business sustainability is a form of consistency in business condition, and it is supported by several factors. They are: the compilation of a business plan, regular business plan updates, analyzing the competitors, the ease of entering a new business and the ability to consider risks.

Business sustainability of SMEs can be seen from the success of the company in terms of innovation, employee and customer management, also return on initial capital. A sustainable company also usually has an orientation to develop and see opportunities for continuous innovation [13]. The measurement of business continuity of SMEs refers to the perceived business performance approach adapted from the Balance Score Card [14].

\subsection{Hypothesis Development}

\section{a) The Effect of Fintech on Financial Literacy}

Fintech helps people more easily get access to financial products and financial literacy [11]. The financial technology (fintech) industry is an attractive method of financial services in today's digital era. The collaboration between banking and fintech can be a solution in increasing financial literacy and inclusion in Indonesia (Vincent, 2019). The presence of fintech is a new breakthrough for the community in making transactions using financial services [5]. It is crucial for SMEs actors to have financial literacy in order to utilize financial technology [25].

The synergy between banking and fintech, that provides payment infrastructure and digital financial transactions, enables Indonesians to transact non-cash and non-card safely and more efficiently, without being constrained by balance limits in their applications. Thus, the 
existence of fintech can increase financial literacy. Based on the description above, the hypothesis is as follows:

H1: Fintech has positive effect on financial literacy

\section{b) The Effect of Financial Literacy on Business Sustainability}

Financial literacy program aims to help Indonesians manage their financial intelligently. A good understanding of financial literacy means that entrepreneurs are able to understand finance so that make an appropriate decision. Thus, SME managers can make complex and strategic decisions in the financial sector, in order to achieve business sustainability. [10] explained, this relationship logically shows that good financial literacy will be able to strategically identify and respond to changes in the business, economic and financial climate. As the result, the right decisions are made to create innovative and targeted solutions in order to achieve business sustainability. Based on the description above, the hypothesis is formulated as follows:

H2: Financial literacy has positive effect on business sustainability

\section{c) The Effect of Fintech on Business Sustainability}

Fintech companies provide easier and safer digital payments for businesses, so it can attract more consumers and give benefits for SMEs players. The presence of fintech is one of the solutions to overcome problems, especially for people who live far from the city and for people who are classified as unbanked [23]. Moreover, the existence of financial planner services will provide several applications that offer financial management services. These applications help to manage business finances such as recording expenses, monitoring investment performance, buying and selling shares and financial consulting. The number of consumers result a profit for SMEs, which in the end the business can survive and even increase. Based on the description above, the hypothesis is:

H3: Fintech has positive effect on business sustainability

\section{d) The Role of Financial Literacy Mediates the Relationship between Fintech and Business Sustainability}

Fintech will help SMEs to find facilities and solutions in the financial sector. Loans can be assessed from various aspects, not only relying on business credit scores. As the result, SMEs can manage all their financial processes transparently and effectively. SMES actors who understand knowledge in the field of financial literacy, they can make the best decisions. SME actors are also able to adapt to the digital world in the financial sector through the use of fintech companies. Therefore by understanding fintech, it will give benefir for MSMEs' business in the future. Furthermore, the business can develop properly, so that business sustainability can be maintained. Based on the description above, the hypothesis is formulated as follows:

H4: Financial literacy moderates the relationship between fintech and business sustainability

Based on the explanation above, the research model can be drawn as follows: 


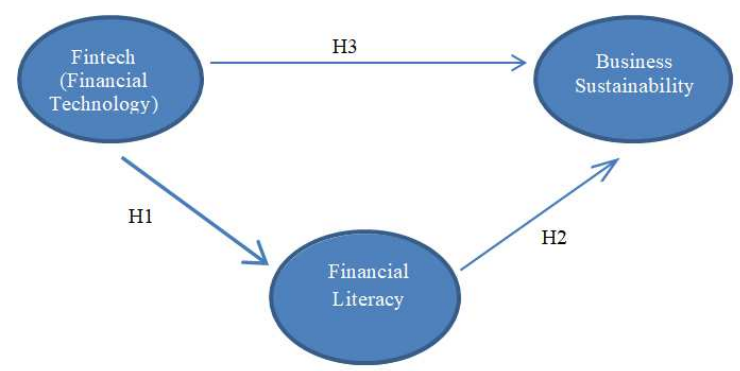

Fig. 1. Research Framework model

\section{Research Method}

The population in this study were SME actors in Semarang, Kudus and Surakarta of Central Java. The sampling technique was using purposive sampling method. with the following criteria:

a) The business has been running for at least 2 years

b) Make records of existing transactions

c) The minimum market target is local market

\subsection{Data Sources and Types}

The data used in this research were primary data obtained from questionnaires. The questionnaires were distributed to a number of SME actors in Semarang, Kudus and Surakarta.

\subsection{Data Collecting Method}

The data collection method used in this study is questionnaire method In the measurement, each respondent was asked for his opinion regarding a statement measured on a Likert scale from 1 to 5 which means 1: strongly disagree; 2: disagree, 3: neutral, 4: agree, 5: strongly agree.

\subsection{Variable and Indicator}

The variables used in this study consisted of one independent variable, namely fintech (X), and mediation variable, namely financial literacy (Y1) and business sustainability (Y2). The relationship between the dependent and independent variables will be tested separately to obtain specific results. It is related to the influence of the independent variable on the dependent variable and the presence of the mediating variable. The following are the assessment indicators of each variable:

Table 1. Assessment Indicators of Each Variable

\begin{tabular}{ll}
\hline \multicolumn{1}{c}{ Variable } & \multicolumn{1}{c}{ Indicator } \\
\hline Fintech $(\mathrm{X} 1)$ & 1. The use of market aggregator \\
& 2. Risk and investment management \\
Financial Literacy $\left(\mathrm{Y}_{1}\right)$ & 3. Understanding on financial technology \\
\hline
\end{tabular}




\begin{tabular}{cl}
\hline Variable & \multicolumn{1}{c}{ Indicator } \\
\hline & 2. Financial behavior \\
Business Sustainability $\left(\mathrm{Y}_{2}\right)$ & 3. Financial attitude \\
& 2. BEP (Break Event Point) \\
& 3. Emplomer satisfaction tracking system \\
\hline
\end{tabular}

\subsection{Data Analysis Technique}

The data used in this study were analyzed by using descriptive analysis method. In data management, researchers used SPSS version 26 and the analysis techniques included: descriptive statistical test, data quality test, classical assumption test, and hypothesis test.

\subsection{Descriptive Statistic Analysis}

Descriptive statistic uses to provide an overview of the variables studied. Descriptive statistical test includes range, minimum value, maximum value, average value (mean), and standard deviation of the data for each variable.

\subsection{Data Quality Test}

\section{a) Validity Test}

Validity is a condition that describes the level of the ability of an instrument in question in measuring what will be measured [28]. The questionnaire used in a study must be valid.

\section{b) Reliability Test}

Reliability is actually a tool to measure a questionnaire as an indicator of a variable or construct. In order to find out whether a variable is reliable or not, a statistical test is performed by looking at the Cronbach Alpha $(\alpha)$. The criteria used are a construct or variable that is considered be reliable if it has a Cronbach Alpha value for $>0.70$ [28].

\subsection{Classical Assumption Test}

\section{a) Normality Test}

Normality test aims to test whether in the regression model, disturbance variable or residual have a normal distribution.

\section{b) Multicollinearity Test}

According to [28], multicollinearity test aims to test whether in the regression there is a correlation between independent variables.

\section{c) Heteroscedasticity Test}

Heteroscedasticity test is used to test whether the regression model has variants inequality from the residuals of one observation to another [28]. It is called heteroscedasticity if the 
variants of the residuals from an observation are different. However, if the residual variant from one observation to another is constant, it is called homocedasticity.

\subsection{Regression Analysis}

Simple regression analysis is used to simply predict the value of a dependent variable based on the value of other variables. Regression analysis can also be used to see the effect of the independent variable $(\mathrm{X})$ on the dependent variable $(\mathrm{Y})$. This is to determine whether there is an effect between the independent variable $(\mathrm{X})$ and the dependent variable $(\mathrm{Y})$. In this study, the regression formulation is as follows:

$$
\mathrm{Y}_{1}=\beta_{01}+\beta 1 \mathrm{X}+\mathrm{e} \mathrm{Y}_{2}=\beta_{02}+\beta 2 \mathrm{Y} 1+\mathrm{e}
$$

Description:

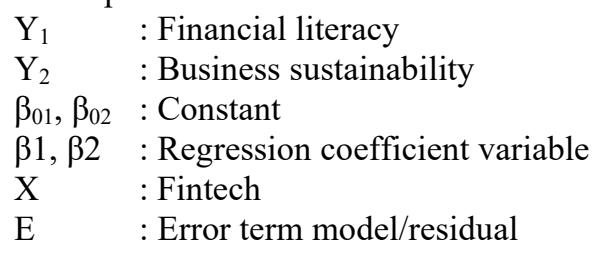

\subsection{Model Feasibility}

\section{a) F Statistic Test}

The $\mathrm{F}$ statistical test aims to provide an overall picture. The independent variables in the study have a joint effect on the dependent variable. If the significance value is $<0.05$, the independent variable has an effect on the dependent variable, and vice versa if the significance value is $>0.05$ then the independent variable has no effect on the dependent variable.

\section{b) Determination Coefficient Test (Adjust $\mathbf{R}^{2}$ )}

The determination coefficient (adjusted $\mathrm{R}^{2}$ ) test is used to find out how far the model's ability to explain variations in the dependent variable [28]. A value close to 1 means that the independent variable provides almost all the information needed to predict the variation in the dependent variable.

\section{c) Hypothesis Test (t-test)}

The $t$ test is used to determine the individual influence between each independent variable in explaining the dependent variable. Below is statistical hypothesis:

1) $\mathrm{H}_{0}: \beta_{1} \leq 0$, means fintech has no effect on financial literacy

2) $\mathrm{H}_{\mathrm{a}}: \beta_{1}>0$, means fintech has positive effect on financial literacy

3) $\mathrm{H}_{0}: \beta_{2} \leq 0$, means financial literacy has no effect on business sustainability

4) $H_{a}: \beta_{2}>0$, means financial literacy has positive effect on business sustainability

5) $\mathrm{H}_{0}: \beta_{3} \leq 0$, means fintech has no effect on business sustainability

6) $\mathrm{H}_{\mathrm{a}}: \beta_{3}>0$, means fintech has positive effect business sustainability

By the hypothesis test, it considered; a. $\alpha$ significant level is $5 \%$, b. criteria for acceptance / 
rejection of Ho pay attention to significant values, c. the intervening variable (mediation) causes direct and indirect test.

\section{Result and Discussion}

\subsection{Validity Test}

Based on the validity test, all instruments show valid results.

\subsection{Reliability Test}

Reliability test shows the three variables, namely fintech, financial literacy and reliable business sustainability. The following are the results of the reliability test:

Table 2. Reliability Test Result

\begin{tabular}{clll}
\hline No & \multicolumn{1}{c}{ Variable } & Cronbach's Alpha & Information \\
\hline 1 & Fintech & 0.862 & Reliable \\
2 & Financial literacy & 0.835 & Reliable \\
3 & Business sustainability & 0.761 & Reliable \\
\hline
\end{tabular}

\subsection{Classical Assumption Test}

\section{a) Normality Test}

The normality test aims to test whether in the regression model the disturbance variable or residual have a normal distribution or not. The following is the result of the normality test for the fintech variable on financial literacy.

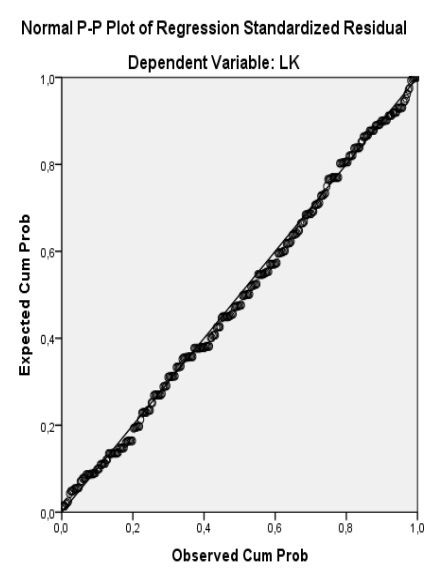

Fig. 2. The Result of Normality Test

In figure 2 above the normal p-p plot graph shows that the normal p-p plot graph is normally distributed. It is because the data spreads out and follows the direction of the diagonal line. Following are the results of normality test with the Kolmogorov-Smirnov (K-S) statistical test: 
Table 3. Normality Test Result One-Sample Kolmogorov-Smirnov Test

\begin{tabular}{|c|c|c|}
\hline \multicolumn{3}{|c|}{ One-Sample Kolmogorov-Smirnov Test } \\
\hline & & ed Residual \\
\hline \multicolumn{2}{|l|}{$\mathrm{N}$} & 300 \\
\hline \multirow[t]{2}{*}{ Normal Parameters ${ }^{\mathrm{a}, \mathrm{b}}$} & Mean & .0000000 \\
\hline & Std. Deviation & 8,13963257 \\
\hline \multicolumn{2}{|c|}{ Most Extreme DifferencesAbsolute } & .036 \\
\hline & Positive & .036 \\
\hline & Negative & -.025 \\
\hline & .036 \\
\hline \multirow{2}{*}{\multicolumn{2}{|c|}{ Asymp. Sig. (2-tailed) }} & $.200^{\mathrm{c}}$ \\
\hline \multirow{2}{*}{\multicolumn{3}{|c|}{$\begin{array}{l}\text { a. Test distribution is Normal. } \\
\text { b. Calculated from data. }\end{array}$}} \\
\hline & & \\
\hline \multicolumn{3}{|c|}{ c. Lilliefors Significance Correction. } \\
\hline
\end{tabular}

Based on table 3, the normality test by Kolmogrov-Smirnov with a significance level of 0.200 indicates that it is greater than 0.05 . In conclusion, the disturbance variable or residual is normally distributed and $\mathrm{H} 0$ is accepted.

\section{b) Multicolonierity Test Result}

Table 4. Multicolonierity Test Result

\begin{tabular}{|c|c|c|}
\hline \multicolumn{3}{|c|}{ Coefficients $^{a}$} \\
\hline \multirow{2}{*}{ Model } & \multicolumn{2}{|c|}{ Collinearity Statistics } \\
\hline & Tolerance & VIF \\
\hline Fintech & 1.000 & 1.000 \\
\hline a. $\mathrm{De}$ & dent Variabl & ial literacy \\
\hline
\end{tabular}

Based on table 4, the VIF value of each variable is $<10$. This indicates that for the independent variable, there is no multicollinearity to the dependent variable. It can be concluded that the regression model does not experience multicollinearity symptom.

\section{c) Multicollinearity test of Fintech and Financial Literacy variables on Business Sustainability}

Table 5. Multicollinearity test of Fintech and Financial Literacy Variables on Business Sustainability

\begin{tabular}{|c|c|c|}
\hline \multicolumn{3}{|c|}{ Coefficients $^{\mathrm{a}}$} \\
\hline \multirow{2}{*}{ Model } & & arity Statistics \\
\hline & Tolerance & VIF \\
\hline Fintech & 0.954 & 1.049 \\
\hline Financial Literacy & 0.954 & 1.049 \\
\hline
\end{tabular}

Based on table 5, the VIF value of each variable is $<10$. This shows that for the independent variable there is no multicollinearity to the dependent variable. It is because the VIF value does not exceed the value of 10 and for the tolerance value approaches the number 1 (tolerance exceeds 0.1 ). It can be concluded that the regression model does not experience multicolonierity symptoms. 


\section{d) Heteroscedasticity Test Result}

Table 6. Heteroscedasticity Test Result

\begin{tabular}{|c|c|c|c|c|c|c|}
\hline \multicolumn{7}{|c|}{ Coefficients $^{\mathrm{a}}$} \\
\hline & \multirow{2}{*}{ Model } & \multicolumn{2}{|c|}{ Unstandardized Coefficients } & \multirow{2}{*}{$\frac{\text { Standardized Coefficients }}{\text { Beta }}$} & \multirow{2}{*}{ t } & \multirow{2}{*}{ Sig. } \\
\hline & & $\mathbf{B}$ & Std. Error & & & \\
\hline \multirow[t]{3}{*}{1} & (Constant) & 7,421 & 0,886 & & 8,373 & 0,000 \\
\hline & Fintech & $-0,095$ & 0,082 & $-0,067$ & $-1,153$ & 0,250 \\
\hline & Dependent & Variable : AbsUt & & & & \\
\hline
\end{tabular}

According to the test result, it shows that the significance value is greater than 0.05 . so it can be concluded that this study is free from heteroscedasticity symptom.

e) Heteroscedasticity Test of Fintech and Financial Literacy for Business Sustainability

Table 7. Heteroscedasticity Test of Fintech and Financial Literacy for Business Sustainability

\begin{tabular}{|c|c|c|c|c|c|c|}
\hline \multicolumn{7}{|c|}{ Coefficients $^{\mathbf{a}}$} \\
\hline & \multirow[t]{2}{*}{ Model } & \multicolumn{2}{|c|}{$\begin{array}{c}\text { Unstandardized } \\
\text { Coefficients }\end{array}$} & \multirow{2}{*}{$\begin{array}{c}\begin{array}{c}\text { Standardized } \\
\text { Coefficients }\end{array} \\
\text { Beta } \\
\end{array}$} & \multirow[t]{2}{*}{$\mathbf{t}$} & \multirow[t]{2}{*}{ Sig. } \\
\hline & & B & Std. Error & & & \\
\hline \multirow[t]{3}{*}{1} & (Constant) & 3,996 & 0,653 & & 6,123 & 0,000 \\
\hline & Fintech & $-0,114$ & 0,042 & $-0,161$ & $-2,742$ & 0,065 \\
\hline & Financial Literacy & 0,019 & 0,017 & 0,065 & 1,101 & 0,272 \\
\hline b. & Dependent Variable : & & & & & \\
\hline
\end{tabular}

According to the test results, the significance value is greater than 0.05 . In conclusion, this study is free from heteroscedasticity symptom.

\subsection{Linier Regression Analysis}

A good multiple regression model is a model that meets the criteria of classical assumptions. The criteria are disturbance variable or residuals that are normally distributed, free from multicollinearity, avoid autocorrelation and there is no any heteroscedasticity. From the previous analysis, it is proven that the model in this study meets the criteria of classical assumptions, so that the model in this study is considered as good model.

Table 8. Regression Test

Multiple Linear Regression Analysis (Fintech $\rightarrow$ Financial Literacy)

\begin{tabular}{|c|c|c|c|c|c|c|}
\hline \multicolumn{7}{|c|}{ Coefficients $^{\mathbf{a}}$} \\
\hline & \multirow{2}{*}{ Model } & \multicolumn{2}{|c|}{ Unstandardized Coefficients } & \multirow{2}{*}{$\begin{array}{c}\text { Standardized Coefficients } \\
\text { Beta } \\
\end{array}$} & \multirow{2}{*}{$\mathbf{T}$} & \multirow{2}{*}{ Sig. } \\
\hline & & B & Std. Error & & & \\
\hline 1 & (Constant) & 27,848 & 1,462 & & 19,049 & 0,000 \\
\hline \multicolumn{7}{|c|}{ a. Dependent Variable: Financial Literacy } \\
\hline
\end{tabular}

The regression equation is as follows:

$$
\mathrm{Y}=27.848+0,516 \llbracket \mathrm{X} \rrbracket \_1+\epsilon
$$


Multiple Linear Regression Analysis of Fintech and Financial Literacy variables on Business Sustainability

Table 9. Regression Test

\begin{tabular}{|c|c|c|c|c|c|c|}
\hline \multicolumn{7}{|c|}{ Coefficients $^{\mathrm{a}}$} \\
\hline & \multirow[t]{2}{*}{ Model } & \multicolumn{2}{|c|}{$\begin{array}{c}\text { Unstandardized } \\
\text { Coefficients }\end{array}$} & \multirow{2}{*}{$\begin{array}{c}\begin{array}{c}\text { Standardized } \\
\text { Coefficients }\end{array} \\
\text { Beta } \\
\end{array}$} & \multirow[t]{2}{*}{$\mathbf{T}$} & \multirow[t]{2}{*}{ Sig. } \\
\hline & & B & Std. Error & & & \\
\hline \multirow[t]{4}{*}{1} & (Constant) & 14,397 & 1,141 & & 12,621 & 0,000 \\
\hline & Fintech & 0,258 & 0,073 & 0,182 & 3,544 & 0,000 \\
\hline & Financial Literacy & 0,257 & 0,030 & 0,434 & 8,459 & 0,000 \\
\hline & oendent Variable: B & Sustainal & & & & \\
\hline
\end{tabular}

The regression equation is as follows:

$$
\mathrm{Y}=14.397+0,258 \llbracket \mathrm{X} \rrbracket \_1+0,257 \mathrm{X} \_2+\epsilon
$$

\subsection{Model Feasibility Test}

\section{a) F Statistic Test}

The $\mathrm{F}$ test aims to determine whether the independent variables can influence the dependent variable or not.

Table 10. Fintech Variable Statistical Test on Financial Literacy

\begin{tabular}{|c|c|c|c|c|c|}
\hline \multicolumn{6}{|c|}{ ANOVA $^{a}$} \\
\hline Model & Sum of Squares & df & Mean Square & $\mathbf{F}$ & Sig. \\
\hline Regression & 962,315 & 1 & 962,315 & 14,476 &, $000^{\mathrm{b}}$ \\
\hline Residual & 19809,832 & 298 & 66,476 & & \\
\hline Total & 20772,147 & 299 & & & \\
\hline $\begin{array}{l}\text { a. Dependent V } \\
\text { b. Predictors: (C }\end{array}$ & $\begin{array}{l}\text { iable: Financial L } \\
\text { nstant): Fintech }\end{array}$ & racy & & & \\
\hline
\end{tabular}

Table 10 shows that the significance level of 0.00 is smaller than 0.05 . This means that the regression model can be used to predict financial literacy.

b) Fintech Statistical Test for Fintech Variables and Financial Literacy on Business Sustainability

Table 11. Fintech Statistical Test for Fintech Variables

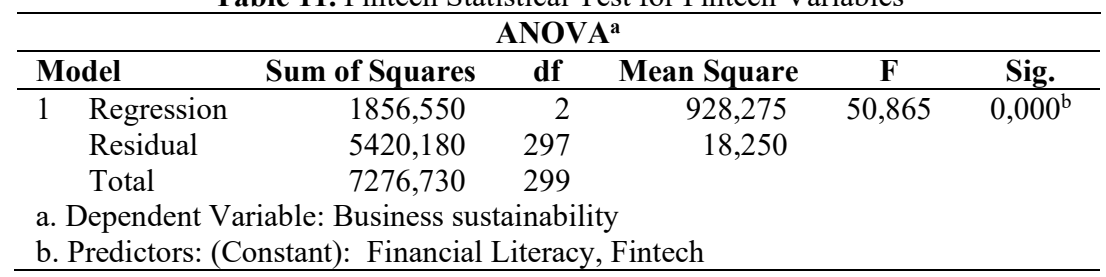

Table 11 shows that the significance level of 0.000 is less than 0.05 . This means that the regression model can be used to predict business sustainability or the fintech and financial literacy variable have an effect on business sustainability. 


\section{c) Coefficient Determination Test (Adjusted $\mathbf{R}^{2}$ )}

The determination coefficient is useful for measuring how far the entire independent variable can explain the dependent variable.

Table 12. Coefficient Determination Test

\begin{tabular}{lcccr}
\hline \multicolumn{4}{c}{ Model Summary $^{\mathbf{b}}$} \\
\hline Model & $\mathbf{R}$ & R Square & Adjusted R Square & Std. Error of the Estimate \\
\hline 1 &, $215^{\text {a }}$ &, 046 &, 043 & 8,153 \\
a. Predictors: (Constant), Fintech & & \\
b. Dependent Variable: Financial Literacy & \\
\hline
\end{tabular}

Based on the table above, it is obtained the Adjusted R Square value is 0.043 or $4.3 \%$. This indicates that the contribution of financial literacy variable is $4.3 \%$ and the remaining $95.7 \%$ is influenced by other variables outside the research.

d) Fintech Variable Determination Coefficient Test, Financial Literacy on Business Sustainability

Table 13. Fintech Variable Determination Coefficient Test

\begin{tabular}{lcccr}
\hline & \multicolumn{3}{c}{ Model Summary $^{\mathbf{b}}$} \\
\hline Model & $\mathbf{R}$ & R Square & Adjusted R Square & Std. Error of the Estimate \\
\hline 1 & $0,505^{\text {a }}$ & 0,255 & 0,250 & 4,272 \\
a. Predictors: (Constant), Financial Literacy, Fintech & \\
b. Dependent Variable: Business Sustainability & \\
\hline
\end{tabular}

Based on the table above, it is obtained the Adjusted R Square value is 0.250 or $25 \%$. This indicates that the contribution of the financial literacy variable is $25 \%$ and the remaining $75 \%$ is influenced by other variables outside the research.

\subsection{Hypothesis Test}

\section{a) The Effect of Fintech on Financial Literacy}

Based on test results, it can be concluded that the fintech variable has a regression coefficient value of 0.516 in a positive direction and with a significant value of 0.00 , less than 0.05 . This means that fintech variable has a positive effect on financial literacy thus the first hypothesis is accepted.

\section{b) The Effect Financial Literacy on Business Sustainability}

Based on the test result, it can be concluded that the financial literacy variable has a regression coefficient value of 0.257 in a positive direction and with a significant value of 0.00 , less than 0.05 . This means that the financial literacy variable has a positive effect on business sustainability, thus the second hypothesis is accepted. 


\section{c) The Effect of Fintech on Business Sustainability}

Based on test result, it can be concluded that the financial literacy variable has a regression coefficient value of 0.258 in a positive direction and with a significant value of 0.00 , less than 0.05 . This means that the financial literacy variable has a positive effect on business continuity, so that the second hypothesis is accepted.

\section{d) The Role of Financial Literacy as Moderating Variable in the Relationship between Fintech and Business Sustainability}

Based on the results of data processing, it shows that the indirect effect of fintech has a positive effect on business sustainability through financial literacy. These results indicate that the better understanding of fintech and supported by the ability in the field of financial literacy, the results will have a significant impact on improving SMEs business sustainability. Thus the results of this study provide evidence that financial literacy in the relationship between fintech and business sustainability is significant.

\section{Conclusion}

The conclusions of this study are; first, fintech is proven to have an effect on financial literacy. This shows that the synergy between fintech and banking that provides digital financial payments and transactions allows Indonesians to transact efficiently and safely without being constrained by balance limit in their applications. Second, financial literacy is proven to have a positive effect on business sustainability. Therefore, SMEs managers can make complex and strategic financial decisions in order to achieve business sustainability. Third, fintech is proven to have an effect on business sustainability. Fintech understanding gives an easier and safer digital payment for business people, so it attracts consumers and give benefits for business actors. The number of consumers will make a profit for SMEs which in the end the business can survive and even increase. The last, financial literacy has been proven to mediate the fintech relationship with business sustainability. This means that business actors must understand knowledge in the field of financial literacy in order to make the best decisions. Furthermore, it also makes the business can develop properly, so that business sustainability can be maintained.

There are two suggestions of this study, first for the SMEs not only develop the role of fintech as payment but for other purposes such as financing, financial arrangements, investment and others. Second, for business actors, they should increase their knowledge in the field of software applications that are trending in the digital era in accordance with current digital development.

\section{References}

[1] Abanis, T. (2013). Financial Management Practice in Small and Medium Enterprises in Selected Districts in Western Uganda. Research Journal of Finance and Accounting, Vol 4 (2), 29-42.

[2] Anggraeni, B. (2015). Pengaruh Literasi Keuangan Pemilik Usaha Terhadap Pengelolaan Keuangan Studi Kasus: UMKM Depok. Jurnal Vokasi Indonesia, Vol 3 (1),22-30. 
[3] Ayu, A. (2018). Transformasi Digital sebagai Upaya Adaptif dalam Meningkatkan Pendapatan di Era Disruption"(Studi Pada Bosowa Taksi Makassar) (Doctoral dissertation, Universitas Islam Negeri Alauddin Makassar).

[4] Braunstein, S.,dan Welch, C. 2002. Financial Literacy: An Overview of Practice, Research, and Policy. USA: Federal Reserve Bulletin

[5] Burhanuddin, C. I., \& Abdi, M. N. (2019). Tingkat Pemahaman dan Minat Masyarakat dalam Penggunaan Fintech. Owner, 3(1), 21-27.

[6] CNBC Indonesia, 2018, "Ini Dia Empat Jenis Fintech di Indonesia", https:/www.cnbcindonesia.com/fintech/20180110145800-37-1126/ini-dia-empat-jenisfintech-di-indonesia

[7] Cooper, A. C., F. J. Gimeno-Gascon, dan C. Y. Woo. 1994. Initial human and financial capital as predictors of new venture performance. Journal of Business Venturing. 9(5). 371-395

[8] Daily Social. (2018). Fintech Report. p. 16-35. https://ailysocial.id/report/post/fintechreport2018 (accessed 10 November 2019).

[9] Definit, O. \&. (2013). Final Report Developing Indonesian Financial Literacy Index. Jakarta: OJK.

[10] Draxler, A., Fischer, G., dan Schoar, A. 2014. Keeping it simple: Financial literacy and rules of thumb. American Economic Journal: Applied Economics. 6(2). 1-31.

[11] Finansialku.com, 2018, "Definisi Fintech", https://www.finansialku.com/definisifintech- adalah/.

[12] Fitriani, H. (2018). KONTRIBUSI FINTECH DALAM MENINGKATKAN KEUANGAN INKLUSIF PADA PERTANIAN (Studi Analisis Melalui Pendekatan Keuangan Syariah Dengan Situs Peer To Peer Lending Pada Pertanian Di Indonesia). El-Barka: Journal of Islamic Economics and Business, 1(1), 1-26.

[13] Hudson, M., A. Smart and M. Bourne. 2001. Theory and practice in SME performance measurement systems. International Journal of Operations \& Production Management. 21(8). 1096- 1115.

[14] Kaplan, R.S, dan Norton, D.P. 2005. The balanced scorecard - Measures that drive performance. Harvard Business Review. 83(7). 172.

[15] Koinwork.com, 2018, "Semua yang Perlu Anda Ketahui Tentang Peer to Peer Lending (P2P Lending". https://koinworks.com/blog/ketahui-tentang-peer-peer-lending/.

[16] Luckandi. Diardo, 2018, “Analisis Transaksi Pembayaran Menggunakan Fintech Pada UMKM di Indonesia: Pendekatan Adaptive Structuration Theory", Tesis. Universitas Islam Indonesia

[17] Lusardi, A. 2012. Numeracy, financial literacy, and financial decision-making (No. w17821). National Bureau of Economic Research.

[18] Indonesia, B. (2015). Profil Bisnis Usaha Kecil, Mikro, dan Menengah (UMKM). www.bi.go.id, IV.

[19] Irma Muzdalifah. Inayah Aulia dan Bella Gita, 2018, "Peran Fintech dalam Meningkatkan Keuangan Inklusif pada UMKM di Indonesia" Jurnal MasharifSyariah Vol. 3, No. 1. Universitas Muhammadiyah Surabaya

[20] Otoritas Jasa Keuangan, 2018, "Penyelenggara Fintech yang Terdaftar di OJK per Agustus 2018". https:/www.ojk.go.id/id/berita-dankegiatan/publikasi/Pages/Penyelenggara-Fintech-Terdaftar-di-OJK-per-Agustus2018.aspx/.

[21] Risnaningsih. (2017). Pengelolaan Keuangan Usaha Mikro dengan Economic Entity Concept. Jurnal Analisa Akuntansi dan Perpajakan, Vol 1 (1), 41-50. 
[22] Rita, M., \& Priyanto, S. H. (2015). Empirical Evidence Penerapan Informasi Akuntansi dan Pengelolaan Keuangan pada UMKM Batik. Prosiding Seminar Nasional 4th UNS SME's Summit \& Awards, 66-67.

[23] Rumondang, A. (2018, April). The Utilization of Fintech (P2P Landing) as SME's Capital Solution in Indonesia: Perspective in Islamic Economics (Qirad). In International Conference of Moslem Society (Vol. 2, pp. 12-22).

[24] Siamsyah. Dhoni, 2016, "Mendorong Crowdfunding untuk Peningkatan Investasi di Indonesia" http://www.kemenkeu.go.id/.

[25] Suharyati, S., \& Sofyan, P. (2019). EDUKASI FINTECH BAGI MASYARAKAT DESA BOJONG SEMPU BOGOR. Jurnal Bakti Masyarakat Indonesia, 1(2).

[26] Wicaksono, E. (2015). Pengaruh Financial Literacy terhadap Perilaku Pembayaran Kartu Kredit pada Karyawan di Surabaya. Finesta, Vol 3 (1),85-90.

[27] Yushita, A. (2017). Pentingnya Literasi Keuangan Bagi Pengeloaan Keuangan Pribadi. Jurnal Nominal, Vol VI (1), 11-26.

[28] Ghozali, I. and Aprilia, K., 2016. Teknik Penyusunan Skala Likert dalam Penelitian Akuntansi dan Bisnis. 